\title{
Hoeflea phototrophica sp. nov., a novel marine aerobic alphaproteobacterium that forms bacteriochlorophyll a
}

\author{
Hanno Biebl, ${ }^{1}$ Brian J. Tindall, ${ }^{2}$ Rüdiger Pukall, ${ }^{2}$ Heinrich Lünsdorf, ${ }^{1}$ \\ Martin Allgaier ${ }^{1} \dagger$ and Irene Wagner-Döbler ${ }^{1}$ \\ ${ }^{1}$ GBF - Gesellschaft für Biotechnologische Forschung mbH, Mascheroder Weg 1, D-38124 \\ Braunschweig, Germany \\ ${ }^{2}$ DSMZ - Deutsche Sammlung von Mikroorganismen und Zellkulturen, Braunschweig, Germany
}

Correspondence Irene Wagner-Döbler iwd@gbf.de
Bacterial photosynthesis appears to contribute, to some extent, to the energy generation of heterotrophs in the open oceans. Kolber et al. (2001) calculated, by extrapolation from measurements of bacteriochlorophyll $a$ in tropical seas, that up to $10 \%$ of the bacterioplankton were potentially capable of photosynthesis. In a recent survey, Schwalbach \& Fuhrman (2005) quantified aerobic anoxygenic phototrophs (AAPs) by means of epifluorescence microscopy and quantitative PCR and found them to constitute 1-2\% of all bacteria in the euphotic zone off the coast of Southern California. In estuarine waters, it has been estimated that AAPs constitute

Published online ahead of print on 25 November 2005 as DOI 10.1099/ijs.0.63958-0.

tPresent address: Leibniz-Institut für Gewässerökologie und Binnenfischerei (IGB), Alte Fischerhütte 2, D-16775 Stechlin-Neuglobsow, Germany.

The GenBank/EMBL/DDBJ accession number of the 16S rRNA gene sequence of strain DFL- $43^{\top}$ is AJ582088.

The phylogenetic position of strains DFL-43 ${ }^{\top}$ and DFL-44 within the $\alpha$ 2 subgroup of the Alphaproteobacteria is shown in a supplementary figure available in IJSEM Online.
$>10 \%$ of total bacteria. We have recently isolated a large number of pigmented strains from different habitats of the North Sea and checked them for the presence of genes for the photosynthetic apparatus, namely the pufL and pufM genes, which code for proteins of the photosynthetic reaction centre (Allgaier et al., 2003). The 16 strains that were positive for these genes were classified into five phylogenetic groups on the basis of their $16 \mathrm{~S}$ rRNA gene sequences. None of them could be assigned to an existing species.

Here we describe a group consisting of five strains that belong to the $\alpha-2$ subgroup of the Proteobacteria and which initially showed the greatest level of $16 \mathrm{~S}$ rRNA gene sequence similarity with Ahrensia kielensis (Ahrens, 1968; Uchino et al., 1998). However, after our phenotypic characterization of these novel strains was completed, the first description of the micro-organism Hoeflea marina was published by Peix et al. (2005). On the basis of $16 \mathrm{~S}$ rRNA gene sequences, the novel strains were found to be more closely related to $H$. marina than to A. kielensis. Both A. kielensis and H. marina were originally described by Ahrens (1968) as marine Agrobacterium species forming star-shaped 
aggregates and were subsequently reclassified (Rüger \& Höfle, 1992; Uchino et al., 1998; Peix et al., 2005). In contrast to related genera and species, the novel strains in this study were able to form photosynthetic pigments, in particular bacteriochlorophyll $a$, if appropriate conditions were provided.

The isolates were obtained from cultures of marine dinoflagellates. Three strains (DFL-13, DFL-33 and DFL-44) were from Alexandrium lusitanicum ME207 and two strains (DFL42 and DFL- $43^{\mathrm{T}}$ ) were from Prorocentrum lima ME130. Both cultures were maintained in the dinoflagellate collection of the Biological Institute of the island of Helgoland (German Bight). Single algal cells were washed and plated onto agar plates prepared with 10 -fold-diluted Difco marine broth 2216. Strains DFL- $43^{\mathrm{T}}$ and DFL- 44 were selected for further characterization.

Colonies of surface cultures were light-beige on full-strength marine broth 2216 (Difco) and wine-red on 10-fold-diluted marine broth. They were of a smooth consistency, relatively flat and exhibited an opaque centre and a translucent halo. The cells were small, short, rods, $0 \cdot 3-0 \cdot 5 \times 0 \cdot 7-2 \cdot 0 \mu \mathrm{m}$
(Fig. 1c) and showed rapid movement. Electron micrographs of shadow-cast cells of strain DFL- $43^{\mathrm{T}}$ showed monotrichous flagellation at one or both poles (Fig. 1a). In strain DFL- $43^{\mathrm{T}}$, distinct capsules were visible around the cells. Ultrathin sections revealed a typical Gram-negative cell-wall structure (Fig. 1b).

For most of the physiological tests, a complex medium was used consisting of $\left(1^{-1}\right) 20 \mathrm{~g}$ sea salts, $3 \mathrm{~g}$ peptone and $0.5 \mathrm{~g}$ yeast extract. If necessary, it was replaced by a mineral medium with sodium acetate as the carbon source (Biebl et al., 2005). The temperature range for growth was determined by using a temperature-gradient shaking incubator (Toyo Kogaku Sangyo) that allowed growth to be followed between 15 and $45^{\circ} \mathrm{C}$ (at increments of $3{ }^{\circ} \mathrm{C}$ ) through periodic measurement of the optical density $(600 \mathrm{~nm})$. Good growth was found between 25 and $33^{\circ} \mathrm{C}$, the optimum being at $31{ }^{\circ} \mathrm{C}$. At $15^{\circ} \mathrm{C}$, the growth rate was only $1 / 5$ th of the maximum rate. No growth occurred above $35^{\circ} \mathrm{C}$. The novel strains were able to grow at $\mathrm{pH}$ values between $5 \cdot 8$ and $9 \cdot 5$. Between $\mathrm{pH} 6.0$ and $9 \cdot 0$, initial culture development was almost the same. Sea salts were required at a concentration of at least $0.5 \%$; concentrations up to $7 \%$ were tolerated.

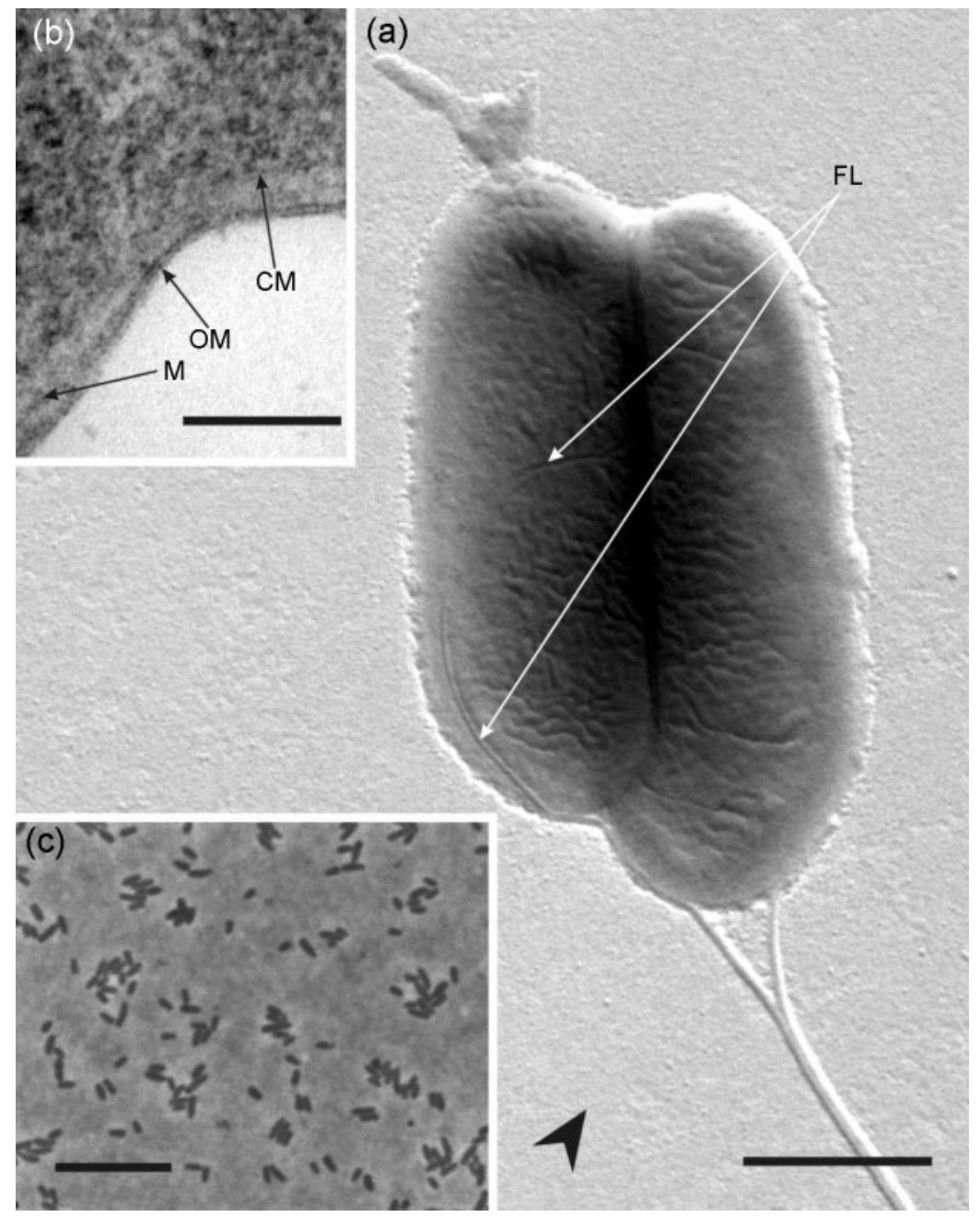

Fig. 1. Morphological features of strain DFL$43^{\top}$. (a) Shadow-cast electron microscopic preparation showing a cell with a monotrichous monopolar flagellum (FL) insertion. The arrowhead indicates the shadowing direction. (b) The Gram-negative cell wall shows an outer membrane (OM) and peptidoglycan as a thin line (M). CM, cytoplasmic membrane. (c) Phase-contrast photomicrograph of cells mounted on an agar surface. Bars: $500 \mathrm{~nm}$ (a), $100 \mathrm{~nm}$ (b) and $10 \mu \mathrm{m}$ (c). 
The utilization of carbon sources was checked in a mineral sea-water medium containing $0 \cdot 1 \mathrm{~g}$ yeast extract $l^{-1}$ to provide the required growth factors. The following carbon sources were tested at a concentration of $1 \mathrm{~g} \mathrm{l}^{-1}$ (acids as sodium salts): acetate, butyrate, succinate, fumarate, malate, lactate, citrate, glutamate, pyruvate, glucose, fructose, ethanol, methanol, glycerol and yeast extract. Moderate growth was obtained only with yeast extract and with acetate or malate. The other substrates tested allowed only limited growth, with $\mathrm{OD}_{600}$ values ranging from 20 (glucose) to $60 \%$ (fumarate, citrate) of that of the acetate culture; methanol and ethanol did not allow any growth at all. In this respect, the novel strains resemble the type strain of A. kielensis, which did not use any of the carbon sources tested (Rüger \& Höfle, 1992). H. marina was found to use a series of sugars and sugar alcohols, including glucose (Peix et al., 2005). Experiments involving culture of the cells with acetate as the substrate and several additives, e.g. yeast extract $\left(0 \cdot 1 \mathrm{~g} \mathrm{l}^{-1}\right)$, vitamin-free and vitamincontaining Casamino acids $\left(0 \cdot 25 \mathrm{~g} \mathrm{l}^{-1}\right.$; Difco $)$ as well as a vitamin solution (consisting of biotin, thiamine, nicotinic acid, pantothenic acid, vitamin $\mathrm{B}_{12}$, pyridoxine and 6aminobenzoic acid), showed that growth factors were required. These growth factors were provided by yeast extract, but not by any of the administered vitamins and amino acids.

The novel strains were unable to decompose or liquefy any of the following polymers: starch, alginate, gelatin and Tween 80 (for lipase activity). They were positive for catalase and oxidase activity, did not form indole from tryptophan and were unable to form nitrite and nitrogen from nitrate under air-exclusion conditions. Antibiotic inhibition was observed with penicillin G, tetracycline and chloramphenicol, but not with polymyxin B. Anaerobic growth by the fermentation of glucose was not observed, but there was some sensitivity to full oxygen exposure, as the growth zone in agar deep culture was distinctly below the surface. No

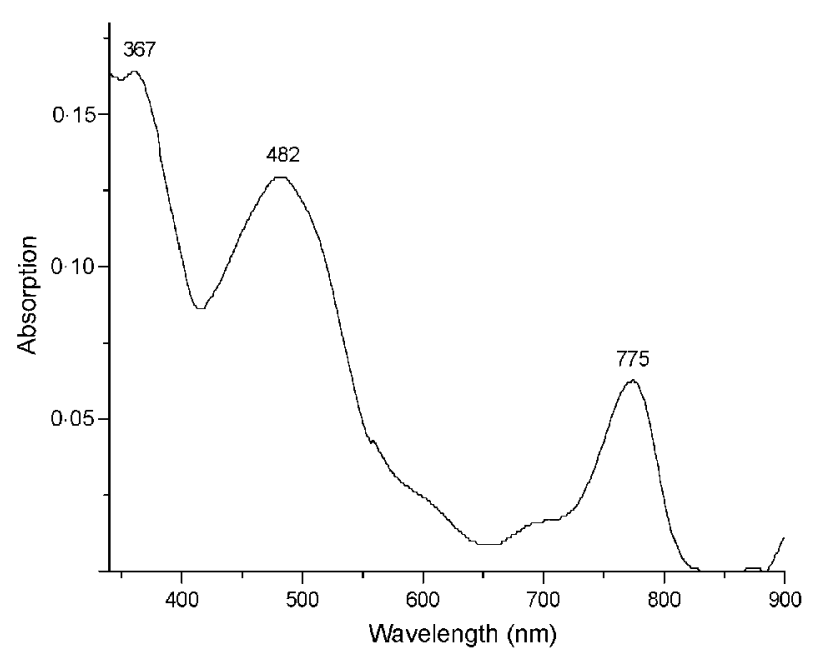

Fig. 2. Absorption spectrum of the acetone/methanol $(7: 2)$ extract of strain DFL-43 ${ }^{\top}$, showing the maxima for bacteriochlorophyll a (367 and $775 \mathrm{~nm}$ ) and a carotenoid (probably spheroidenone).

growth occurred under anaerobic conditions in the light when acetate was the substrate.

In several aerobic phototrophic bacteria (exclusively freshwater organisms), reduction of toxic potassium tellurite to inert elemental tellurium (deposited in the cytoplasm) has been observed (Yurkov et al., 1996). Strains DFL-43 ${ }^{\mathrm{T}}$ and DFL-44 also possessed this capability. After 4 days growth in peptone medium to which $0 \cdot 05-1 \mathrm{~g} \mathrm{l}^{-1}$ potassium tellurite had been added, cultures turned jet-black and refractile inclusions were visible in the cells.

Cellular fatty acids were determined as described by Labrenz et al. (1998). The percentages of fatty acids found in strain DFL $-43^{\mathrm{T}}$ and in H. marina and A. kielensis are shown in

Table 1. Cellular fatty acid content (\%) of strain DFL-43 ${ }^{\top}$ in comparison with those of $H$. marina DSM $16791^{\top}$ and A. kielensis DSM $5980^{\top}$

Fatty acid values of less than $1 \%$ are not shown.

\begin{tabular}{|lccc|}
\hline Fatty acid & DFL-43 & H. marina DSM $\mathbf{1 6 7 9 1}^{\mathrm{T}}$ & A. $^{\mathrm{T}}$ kielensis $\mathbf{D S M} \mathbf{5 9 8 0}^{\mathbf{T}}$ \\
\hline $12: 0$ 3-OH & & & $1 \cdot 0$ \\
$16: 0$ & $6 \cdot 3$ & $4 \cdot 0$ & $1 \cdot 0$ \\
$16: 1 \omega 7$ & $1 \cdot 6$ & $2 \cdot 6$ & $5 \cdot 3$ \\
$18: 0$ & $1 \cdot 2$ & $1 \cdot 4$ & $85 \cdot 0$ \\
$18: 1 \omega 7$ & $62 \cdot 8$ & $76 \cdot 0$ & $3 \cdot 8$ \\
$18: 1 \omega 7$ 11Me & $20 \cdot 6$ & $7 \cdot 5$ & \\
$19: 0$ cyclo & $1 \cdot 6$ & $5 \cdot 6$ & $1 \cdot 6$ \\
$19: 1$ & $3 \cdot 4$ & & \\
$20: 0$ & & & \\
Unknown & $2 \cdot 4$ & & \\
\hline
\end{tabular}


Table 2. Growth and specific bacteriochlorophyll a content of strains of Hoeflea phototrophica sp. nov. in cultures grown at different concentrations of sea salts

\begin{tabular}{|lccccc|}
\hline \multirow{2}{*}{ Sea salts $\left(\mathbf{g ~}^{-\mathbf{1}}\right)$} & \multicolumn{2}{c}{ OD $_{\mathbf{6 0 0}}$} & & \multicolumn{2}{c|}{ Bacteriochlorophyll $\boldsymbol{a}\left(\mathbf{n m o l ~ m g ~ p r o t e i n ~}^{\mathbf{- 1}}\right)$} \\
\cline { 2 - 3 } \cline { 5 - 6 } & DFL-43 $^{\text {T }}$ & DFL-44 & & DFL-43 $^{\text {T }}$ & DFL-44 \\
\hline 3 & 0.31 & 0.36 & & 0.26 & 0.24 \\
6 & 0.65 & 0.48 & & 0.89 & 0.61 \\
9 & 0.66 & 0.54 & & 0.70 & 0.53 \\
35 & 0.53 & 0.59 & & 0.00 & tr \\
\hline
\end{tabular}

Table 1. Strain DFL-44 had almost the same values as strain DFL- $43^{\mathrm{T}}$. As is usually the case for the Alphaproteobacteria, the mono-unsaturated straight chain acid $18: 1 \omega 7$ was the major component (63-85\%), replaced, in part, by the methylated form, particularly in strain DFL- $43^{\mathrm{T}}(21 \%)$. Strain DFL- $43^{\mathrm{T}}, H$. marina and A. kielensis all contained the saturated acids 16:0 and 18:0, albeit in small amounts, whereas the fatty acids $16: 1 \omega 7$ and 19:1 cyclo were found only in strain DFL- $43^{\mathrm{T}}$ and in H. marina. The type strain of A. kielensis contained a hydroxylated $12: 0$ acid and a 20:0 acid that were not found in either strain DFL- $43^{\mathrm{T}}$ or $H$. marina. Polar lipids were extracted and separated by TLC according to Tindall (1990). For strain DFL- $43^{\mathrm{T}}$, phosphatidylglycerol, phosphatidylethanolamine and phosphatidylmonomethylethanolamine were the predominant polar lipids. Moderate amounts of phosphatidylcholine and sulfoquinovosyldiacetylglycerol were present and only minor amounts of diphosphatidylglycerol and an unknown amino lipid were found. Interestingly, A. kielensis contained the same lipids, albeit in somewhat different proportions; in particular, the amount of phosphatidylethanolamine was much lower. $H$. marina differed from the other strains in that it lacked phosphatidylcholine.

Distinct pigmentation was observed on 10-fold-diluted marine agar 2216, but not on the original medium containing $\left(1^{-1}\right) 5 \mathrm{~g}$ peptone, $1 \mathrm{~g}$ yeast extract and about $30 \mathrm{~g}$ salts. Liquid cultures containing $\left(1^{-1}\right) 3 \mathrm{~g}$ peptone and $0 \cdot 5 \mathrm{~g}$ yeast extract and varied amounts of sea salts revealed that pigment production was dependent on the salt concentration. Cultures containing 3, 6 and 9 g sea salts $1^{-1}$ appeared very pink, while cultures at the salt concentration of natural sea water were colourless. The cell mass from $30 \mathrm{ml}$ culture grown at $6 \mathrm{~g}$ sea salts $\mathrm{l}^{-1}$ was extracted with $3 \mathrm{ml}$ acetone/ methanol $(7: 2)$ and the absorption spectrum of the extract was recorded (Fig. 2). It showed the typical maxima of bacteriochlorophyll $a$ at 367 and $775 \mathrm{~nm}$ and a high peak at $482 \mathrm{~nm}$, indicating the presence of a carotenoid. Table 2 shows the specific bacteriochlorophyll $a$ content for both novel strains at the sea salts concentrations indicated. The in vivo absorption spectrum obtained by suspension of cells in $75 \%$ glycerol showed only weak absorption in the infrared region because of the low pigment content, but peaks at around 800 and $865 \mathrm{~nm}$ were recognizable (not shown). It can be inferred that the carotenoid peak (at $482 \mathrm{~nm}$ ) of the solvent extract originates from spheroidenone. The peak was almost identical to that of Dinoroseobacter shibae in which the carotenoid has been identified as spheroidenone (Biebl et al., 2005).

To identify the closest phylogenetic neighbours of strain DFL- $43^{\mathrm{T}}$, 16S rRNA sequences were manually aligned and compared with published sequences from the 16S rRNA gene sequence database of the Deutsche Sammlung von Mikroorganismen und Zellkulturen (Germany), including sequences available from the Ribosomal Database Project (Maidak et al., 2001) and EMBL. Sequences were aligned using the BioEdit program (Hall, 1999). A phylogenetic dendrogram was inferred using DNADIST and the neighbour-joining method of the PHYLIP package (Felsenstein, 1993). Bootstrap analysis was based on 1000 resamplings.

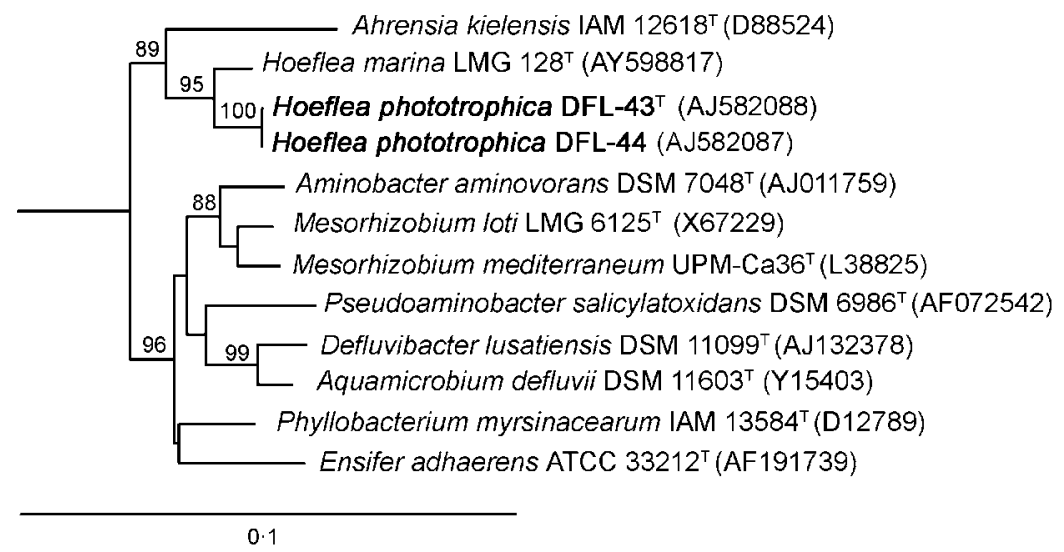

Fig. 3. Neighbour-joining dendrogram based
on $16 \mathrm{~S}$ rRNA gene sequences showing the
phylogenetic position of Hoeflea phototro-
phica DFL- $43^{T}$ in the context of related
genera in the $\alpha-2$ subgroup of the Proteo-
bacteria. Bootstrap values with greater than
$60 \%$ confidence (percentage of 1000
resamplings) are shown at the branching
points. GenBank accession numbers are
given in parentheses. Bar, 10 substitutions
per 100 nt. 
Table 3. Characteristics of Hoeflea phototrophica sp. nov. strains DFL- $43^{\top}$ and DFL-44 that differentiate them from their closest phylogenetic neighbours

Species: 1, H. phototrophica strains DFL- $43^{\mathrm{T}}$ and DFL-44 (data from this study); 2, H. marina DSM $16791^{\mathrm{T}}$ (Peix et al., 2005); 3, A. kielensis DSM $5890^{\mathrm{T}}$ (partly from Ahrens, 1968 and Rüger \& Höfle, 1992). +, Growth; (+), poor growth; -, no growth; NO, not observed.

\begin{tabular}{|c|c|c|c|}
\hline Characteristic & 1 & 2 & 3 \\
\hline Mean cell size $(\mu \mathrm{m})$ & $0.4 \times 1 \cdot 3$ & $0 \cdot 8 \times 1 \cdot 2$ & $0 \cdot 6 \times 2 \cdot 0$ \\
\hline Flagellation & Monotrichous & NO & Peritrichous \\
\hline Bacteriochlorophyll $a$ & + & - & - \\
\hline Sea salts required for growth & + & - & $(+)$ \\
\hline Use of single organic compounds & $(+)$ & + & - \\
\hline Use of glucose & - & + & - \\
\hline Presence of phosphatidylcholine & + & - & + \\
\hline DNA $G+C$ content $(\mathrm{mol} \%)$ & $59 \cdot 3$ & $53 \cdot 1$ & 48 \\
\hline
\end{tabular}

Even though the first variable region of the 16S rRNA gene sequences of strains DFL- $43^{\mathrm{T}}$ and DFL- 44 was more closely related to that of A. kielensis, the almost-complete $16 \mathrm{~S}$ rRNA gene sequences of the novel strains revealed them to be most closely related to $H$. marina. The phylogenetic position of strain DFL- $43^{\mathrm{T}}$ as a novel member within the family Phyllobacteriaceae is shown in Fig. 3. Its phylogenetic position within the $\alpha-2$ subgroup of the Alphaproteobacteria is shown in Supplementary Fig. S1, available in IJSEM Online.

The major phenotypic differences between strains DFL- $43^{\mathrm{T}}$ and DFL-44 and the species with greatest similarity in terms of $16 \mathrm{~S}$ rRNA gene sequence, i.e. H. marina and A. kielensis, are listed in Table 3. Although the 16S rRNA gene sequence comparisons indicate that the novel strains are very close to $H$. marina $(98.5 \%$ similarity) and more distant to $A$. kielensis ( $94.4 \%$ similarity), there are marked phenotypic differences between the novel strains and both of these recognized species and these are also reflected in the wide range of DNA G $+C$ contents. Strains DFL- $43^{\mathrm{T}}$ and DFL44 are distinguished from $H$. marina and $A$. kielensis by possessing bacteriochlorophyll $a$ and carotenoids, possibly enabling them to generate additional energy from light. In addition, they differ from $H$. marina by their smaller cell size, by their inability to grow well in mineral media with defined organic compounds and by the presence of phosphatidylcholine. In contrast to A. kielensis, which has peritrichous flagella, the novel strains described here show monotrichous flagellation. With respect to cell size, substrate utilization and polar lipids, however, the novel strains are more similar to A. kielensis than to H. marina. On the other hand, the cellular fatty acid content of strains DFL$43^{\mathrm{T}}$ and DFL-44 is consistent with a closer relationship to $H$. marina than to A. kielensis. In summary, the molecular data strongly suggest an affiliation of the investigated strains to the genus Hoeflea. The clear morphological and physiological differences, as well as the presence of photosynthesis reaction-centre genes and pigments, indicate that the novel isolates are representatives of a separate species, for which the name Hoeflea phototrophica sp. nov. is proposed. The type strain is DFL $-43^{\mathrm{T}}\left(=\mathrm{DSM} 17068^{\mathrm{T}}=\mathrm{NCIMB}\right.$ $14078^{\mathrm{T}}$ ).

\section{Description of Hoeflea phototrophica sp. nov.}

Hoeflea phototrophica (pho.to'tro.phi.ca. Gr. n. phos photos light; Gr. adj. trophikos nursing, tending or feeding; N.L. fem. adj. phototrophica referring to the likely ability to use light for energy generation).

Cells are small rods, $0 \cdot 3-0 \cdot 5 \times 0 \cdot 7-2 \cdot 0 \mu \mathrm{m}$ in size and are motile by means of single, polarly inserted flagella. Colonies grown on marine agar 2216 are smooth, flat and may form an opaque centre and a translucent halo. They are colourless to slightly beige if grown in the light. Cultures require microaerobic growth conditions, but do not grow anaerobically. Growth occurs at concentrations of sea salts from $0 \cdot 5-7 \cdot 0 \%$, at temperatures of up to $33^{\circ} \mathrm{C}$ (optimum, $31^{\circ} \mathrm{C}$ ) and at $\mathrm{pH}$ values in the range 6-9. Acetate and malate are good growth substrates, whereas succinate, fumarate, lactate, citrate, glutamate, pyruvate, glucose, fructose and glycerol allow only poor growth; ethanol and methanol are not used. Yeast extract is required for growth. Gelatin, starch, alginate and Tween 80 are not decomposed. Nitrate is not reduced to nitrite or nitrogen. Indole is not formed from tryptophan. Cells contain bacteriochlorophyll $a$ and a carotenoid, probably spheroidenone, in small to medium amounts. The DNA $\mathrm{G}+\mathrm{C}$ content of the type strain is $59 \cdot 3 \mathrm{~mol} \%$.

The type strain, DFL- $43^{\mathrm{T}}\left(=\right.$ DSM $\left.17068^{\mathrm{T}}=\operatorname{NCIMB~} 14078^{\mathrm{T}}\right)$, was isolated from a culture of Prorocentrum lima (dinoflagellates).

\section{Acknowledgements}

We thank Dr Michal Koblizek for providing an in vivo absorption spectrum and for tentative identification of the carotenoid. 
Dr Heinz-Martin Schumacher (Deutsche Sammlung von Mikroorganismen und Zellkulturen) is acknowledged for providing a double-beam photometer and for constant advice on its operation.

\section{References}

Ahrens, R. (1968). Taxonomische Untersuchungen an sternbildenden Agrobacterium-Arten aus der westlichen Ostsee. Kieler Meeresforsch 24, 147-173 (in German).

Allgaier, M., Uphoff, H., Felske, A. \& Wagner-Döbler, I. (2003). Aerobic anoxygenic photosynthesis in Roseobacter clade bacteria from diverse marine habitats. Appl Environ Microbiol 69, 5051-5059.

Biebl, H., Tindall, B. J., Koblizek, M., Lünsdorf, H., Pukall, R. \& Wagner-Döbler, I. (2005). Dinoroseobacter shibae gen. nov., sp. nov., a new aerobic phototrophic bacterium isolated from dinoflagellates. Int J Syst Evol Microbiol 55, 1089-1096.

Felsenstein, J. (1993). PHYLIP (phylogeny inference package), version 3.5.1. Distributed by the author. Department of Genome Sciences, University of Washington, Seattle, WA, USA.

Hall, T. A. (1999). BioEdit: a user-friendly biological sequence alignment editor and analysis program for Windows 95/98/NT. Nucleic Acids Symp Ser 41, 95-98.

Kolber, Z. S., Plumley, F. G., Lang, A. S. \& 7 other authors (2001). Contribution of aerobic photoheterotrophic bacteria to the carbon cycle in the ocean. Science 292, 2492-2495.

Labrenz, M., Collins, M. D., Lawson, P. A., Tindall, B. J., Schumann, P. \& Hirsch, P. (1998). Antarctobacter heliothermus gen. nov., sp. nov., a budding bacterium from hypersaline and heliothermal Ekho Lake. Int J Syst Bacteriol 48, 1363-1372.

Maidak, B. L., Cole, J. R., Lilburn, T. G. \& 7 other authors (2001). The RDP-II (Ribosomal Database Project). Nucleic Acids Res 29, 173-174.

Peix, A., Rivas, R., Trujillo, M. E., Vancanneyt, M., Velazquez, E. \& Willems, A. (2005). Reclassification of Agrobacterium ferrugineum LMG 128 as Hoeflea marina gen. nov., sp. nov. Int J Syst Evol Microbiol 55, 1163-1166.

Rüger, H.-J. \& Höfle, M. (1992). Marine star-shaped-aggregateforming bacteria: Agrobacterium atlanticum sp. nov.; Agrobacterium meteori sp. nov.; Agrobacterium ferrugineum sp. nov., nom rev.; Agrobacterium gelatinovorum sp. nov., nom. rev.; and Agrobacterium stellulatum sp. nov., nom. rev. Int J Syst Bacteriol 42, 133-143.

Schwalbach, M. S. \& Fuhrman, J. A. (2005). Wide-ranging abundance of aerobic anoxygenic phototrophic bacteria in the world ocean revealed by epifluorescence microscopy and quantitative PCR. Limnol Oceanogr 50, 620-628.

Tindall, B. J. (1990). Lipid composition of Halobacterium lacusprofundi. FEMS Microbiol Lett 66, 199-202.

Uchino, Y., Hirahata, A., Yakota, A. \& Sugiyama, J. (1998). Reclassification of marine Agrobacterium species: proposals of Stappia stellulata gen. nov., comb. nov., Stappia aggregata sp. nov., nom. rev., Ruegeria atlantica gen. nov., comb. nov., Ruegeria gelatinovora comb. nov., Ruegeria algicola comb. nov., and Ahrensia kielensis gen. nov., sp. nov., nom. rev. J Gen Appl Microbiol 44, 201-210.

Yurkov, V., Jappé, J. \& Verméglio, A. (1996). Tellurite resistance by obligately aerobic photosynthetic bacteria. Appl Environ Microbiol 62, $4195-4198$. 